\title{
Geophysical Investigation for Post Foundation Studies at Ikekogbe Primary School, Ekpoma, Edo State, Nigeria
}

\author{
Aigbedion Isaac ${ }^{1, ~ *, ~ B a w a l l a h ~ M u s a ~}{ }^{1}$, Ilugbo Stephen ${ }^{1}$, Osaigbovo Aize Diana ${ }^{2}$, \\ Diana Emmanuela Kehinde ${ }^{2}$, Ihewkwumere Chinenyeollins ${ }^{2}$, Igbinoba Collins ${ }^{2}$, \\ Patrick Promise Uduak ${ }^{2}$, Amagbamwan Ebenihita ${ }^{2}$ \\ ${ }^{1}$ Department of Applied Geophysics, Federal University of Technology, Akure, Nigeria \\ ${ }^{2}$ Department of Physics, Ambrose Ali University Ekpoma, Edo, Nigeria \\ Email address: \\ isaacaigbedion@yahoo.com (A. Isaac) \\ ${ }^{*}$ Corresponding author
}

\section{To cite this article:}

Aigbedion Isaac, Bawallah Musa, Ilugbo Stephen, Osaigbovo Aize Diana, Diana Emmanuela Kehinde, Ihewkwumere Chinenyeollins, Igbinoba Collins, Patrick Promise Uduak, Amagbamwan Ebenihita. Geophysical Investigation for Post Foundation Studies at Ikekogbe Primary School, Ekpoma, Edo State, Nigeria. American Journal of Environmental and Resource Economics. Vol. 4, No. 2, 2019 , pp. 73-83. doi: 10.11648/j.ajere.20190402.14

Received: May 18, 2019; Accepted: June 26, 2019; Published: July 8, 2019

\begin{abstract}
This research showed the significance of electrical resistivity method for foundation studies at Ikekogbe Primary School, Ekpoma, Edo State, Nigeria. The aim of the study is to assess the building in the area that was intensively affected by cracks resulting in structural instability. The Electrical Resistivity method involved three techniques; Vertical Electrical Sounding (VES), 2-D Electrical Resistivity Tomography (ERT) and Horizontal Profiling (HP) which covers a pilot test of 60 meters. Eight (8) VES were carried out using Schlumberger array with current electrode spacing varying from 1 to $40 \mathrm{~m}$, with 2-D ERT using Dipole-Dipole electrode array with inter-station separation of $5 \mathrm{~m}$ and an expansion factor that varied from 1 to 5 and HP using Wenner array with an electrode spacing of $5 \mathrm{~m}$ interval. The results obtained from the VES delineated three geoelectric units which comprise of topsoil, clayey sand and sandstone formation. The 2 D imaging (Dipole-Dipole) gave information on the subsurface characteristic in the area with low apparent resistivity which indicates low competence material. The Wenner profile is characterised by low resistivity. All the results correlate well with one another showing that all the techniques used are complemented and also deduced that the failures of these buildings arise from incompetent clay materials and lateral inhomogeneity. Evidence has shown that a suspected weak zone cut across the study area and the weak zones contributed a great deal to the cracks observed on the classroom block. The presence of clay materials beneath the classroom also contributed to the cracks observed. It is therefore recommended that future engineering construction should consider possible weak zones before designing or imposed structure as such can instigate failure in the proposed structure.
\end{abstract}

Keywords: Dipole Dipole, Geoelectric Section, Wenner Profiling, Incompetent Materials, Foundation Integrity

\section{Introduction}

The Earth is complex in nature and very inhomogeneous in fracture distribution. The complexity of the earth materials is more pronounced in the basement complex regions while in the sedimentary terrain the soil properties may be fairly uniform over long distance. While some areas are underlain by shallow bedrock or materials of higher load-bearing capacity, others may have significant superficial soil cover $[1,7]$. Incessant failure of buildings has often dominated headlines in Nigeria in recent times and this has generated concerns prompting the entire citizenry to continue to ponder on the causes of the failures of buildings in most part of the country. Previous works over the years in geosciences have attributed these failures to lateral inhomogeneity of the subsurface, differential settlement and failure due to the presence of weak zones beneath the buildings. [2-4, 12] In areas of thick overburden cover, the materials could have variety of engineering properties. While some may be very weak especially where the clay content is high others may be 
of high load bearing capacity especially if the aggregates are gravelly. The rate of failed structures in Nigeria has increased in recent times [11]. This assertion can be attributed to the minimal attention paid towards the use of geophysics in foundation studies. In Engineering Geophysics and site investigation, structural information and physical properties of a site are sought [15]. This is so because the durability and safety of the engineering structural setting depend on the competence of the material, nature of the subsurface lithology and the mechanical properties of the overburden materials [1, 7]. This research is therefore targeted at revealing the use of electrical resistivity approaches as a reliable means of undertaking post construction studies at Ikekogbe Primary School, Ekpoma, Edo State as related to the Geologic nature of the environment thereby saving a lot of time and cost. Also, with the art of these approach, the basic problems of imperative due to the (failure) of buildings in the school and its environs that have emerged problematic can be investigated and remediation actions can be taken.

Site Description and Geology of the Study Area

The study was carried out at Ikekogbe Primary School Eguare-Ekpoma, Edo State, Nigeria (Figure 1). It is situated between the UTM coordinates of Ekpoma datum of Eastings745800 - $746000 \mathrm{~m}$ and Northings 185460 - 185620 $\mathrm{m}$. The elevation ranges from 241.5 to $425.7 \mathrm{~m}$ above the sea level. The area of the study falls within the Anambra Basin covering EguareEkpoma town and Ukpenu extension in Esan West Local Government area of Edo State, Nigeria. Three major formations underlain the study area vis-à-vis Imo shale, Bende-Ameki formation and Ogwashi-Asaba [5, 8, 10, 13]. The area of study is underlain by Bende-Ameki formation, while the nearby area is underlain with $3 \%$ of Imo shale and Ogwashi-Asaba. The area is underlain by clay, shale, sandstone, limestone and sand. The Niger Delta sediment include Basin Agbada and Akata formations and they range in age from Eocene to recent [5].
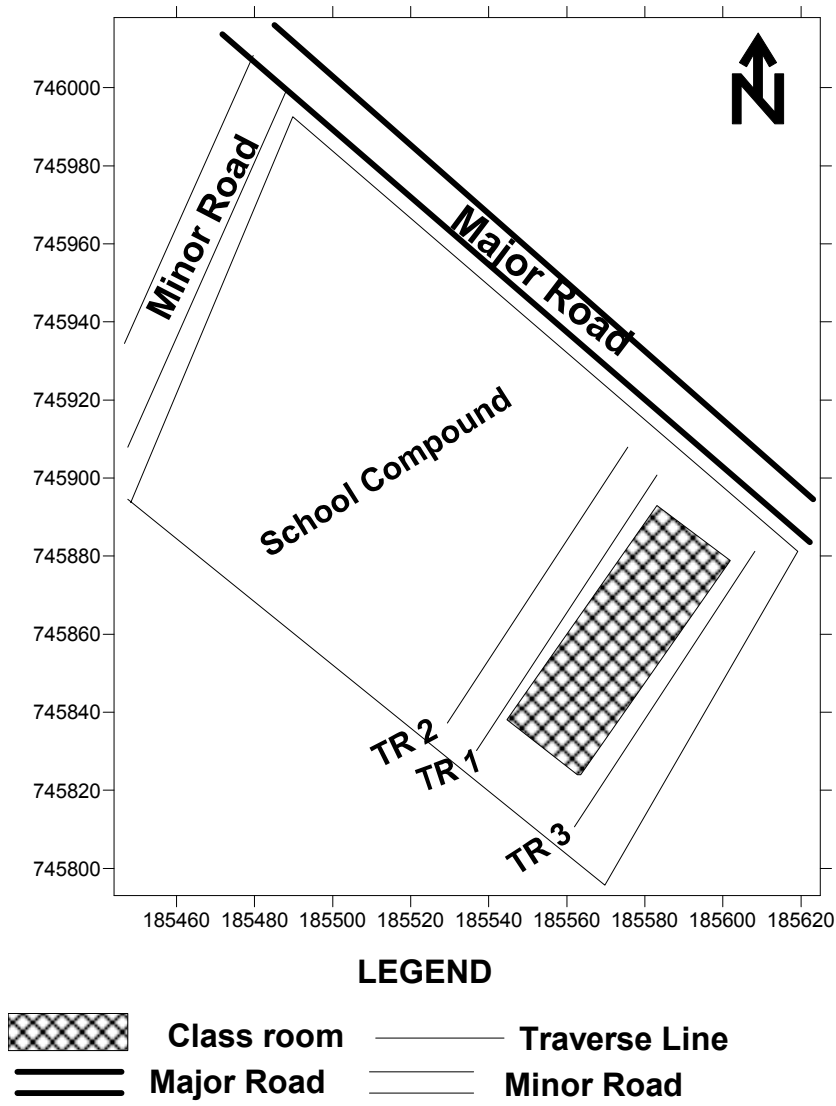

Site Layout

Figure 1. Base Map of the Study Area.

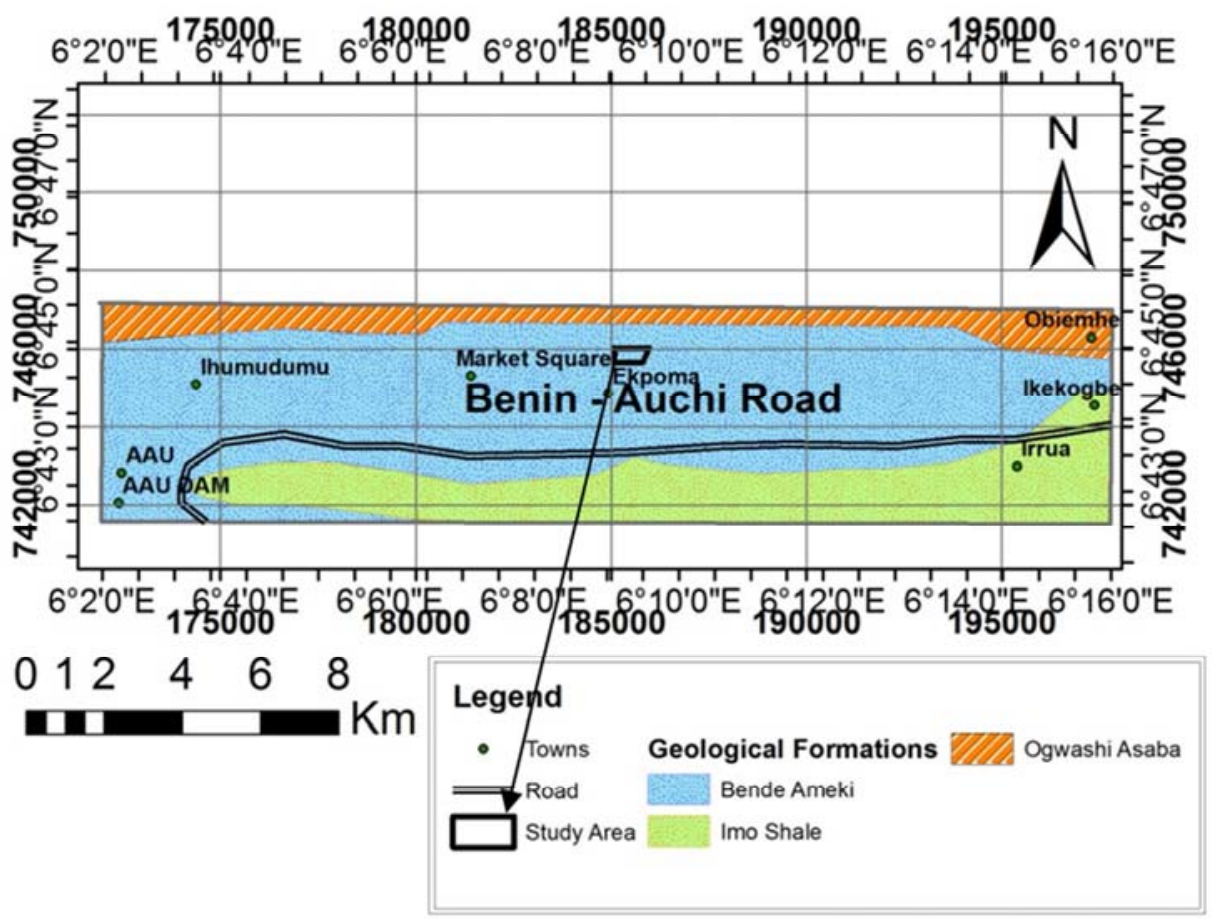

Figure 2. Geological Map of Ekpoma Showing the Study Area (modified after [14]). 


\section{Methodology}

Three traverses of about $50 \mathrm{~m}$ were established in an approximate E - W direction (Figure 3). The electrical resistivity method utilized the horizontal profiling (HP) technique, the vertical electrical sounding (VES) and the combined horizontal profiling and vertical electrical sounding techniques. The horizontal profiling utilizing wenner electrode configuration of station separations and electrode spacing of both $5 \mathrm{~m}$ were used for the traverses. The combined horizontal profiling (HP) and vertical electrical sounding (VES) using dipole-dipole configuration to determine the lateral and vertical variation in apparent resistivity of the subsurface beneath the three established traverses, electrode spacing of $5 \mathrm{~m}$ was used along same traverses as for the wenner electrode configuration. Resistivity values were obtained by taking readings using the R50 resistivity meter. The VES involved the use of Schlumberger array. Eight (8) sounding stations were occupied along the three established traverses, and the current electrode spacing $(\mathrm{AB} / 2)$ was varied from 1 to $40 \mathrm{~m}$. In order to process the electrical resistivity data, the apparent resistivity values were plotted against the electrode spread $(\mathrm{AB} / 2)$. This was subsequently interpreted quantitatively using the partial curve matching method and computerassisted 1-D forward modeling with Win Resist 1.0 version software [16]. The horizontal profiling data were plotted on excel work sheet while the dipole-dipole data were inverted into 2-D subsurface images using the DIPPRO ${ }^{\text {TM }} 4.0$ inversion software [6]. 2-D electrical imaging of the subsurface was obtained using dipole-dipole configuration. The inter-electrode spacing of $5 \mathrm{~m}$ was adopted while interdipole expansion factor (n) was varied from 1 to 5 . Resistivity values were obtained by taking readings using the R50 resistivity meter. The results from the three techniques were integrated in order to determine the consequences of the differential settlement.

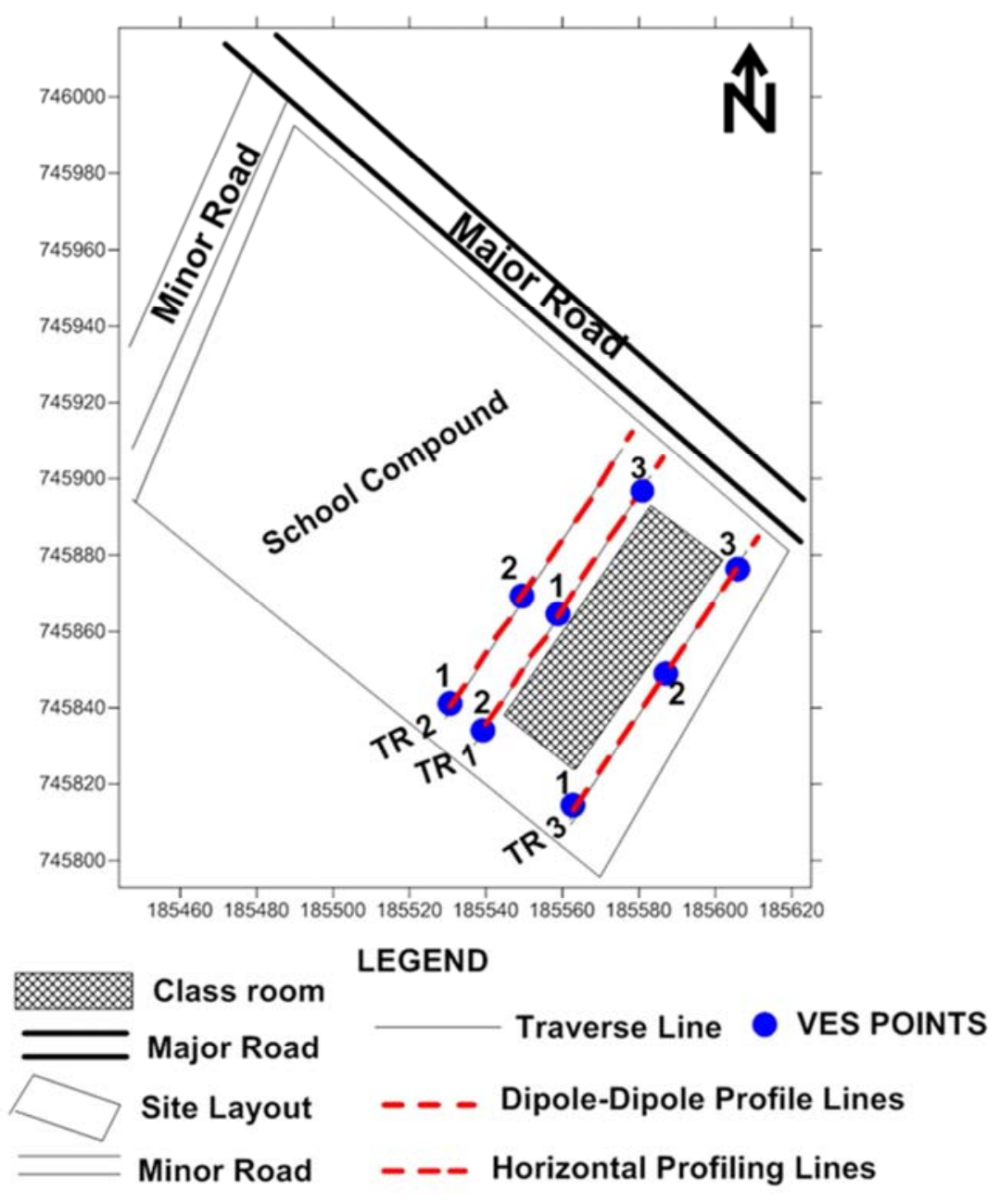

Figure 3. Data Acquisition Map of the Study Area.

\section{Results and Discussion}

The results of the study were presented as Sounding curves geo-electric sections, pseudo sections, and profiles.

\subsection{Characteristic of the VES Curves}

Curves types identified ranges from $\mathrm{A}, \mathrm{KH}$ and $\mathrm{HK}$ varying between three to four geo-electric layers. The A 
curve type was predominating. Typical curve types in the area are as shown in Figure 4(a-c).

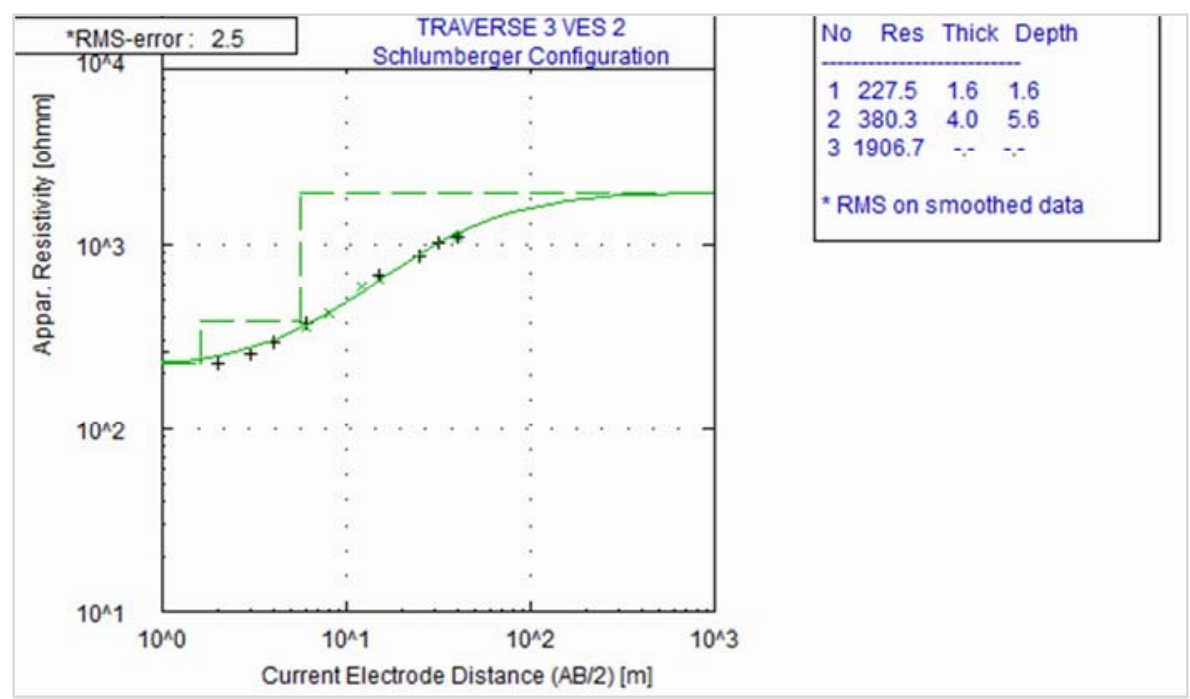

Figure 4. Typical 'A' sounding curve.

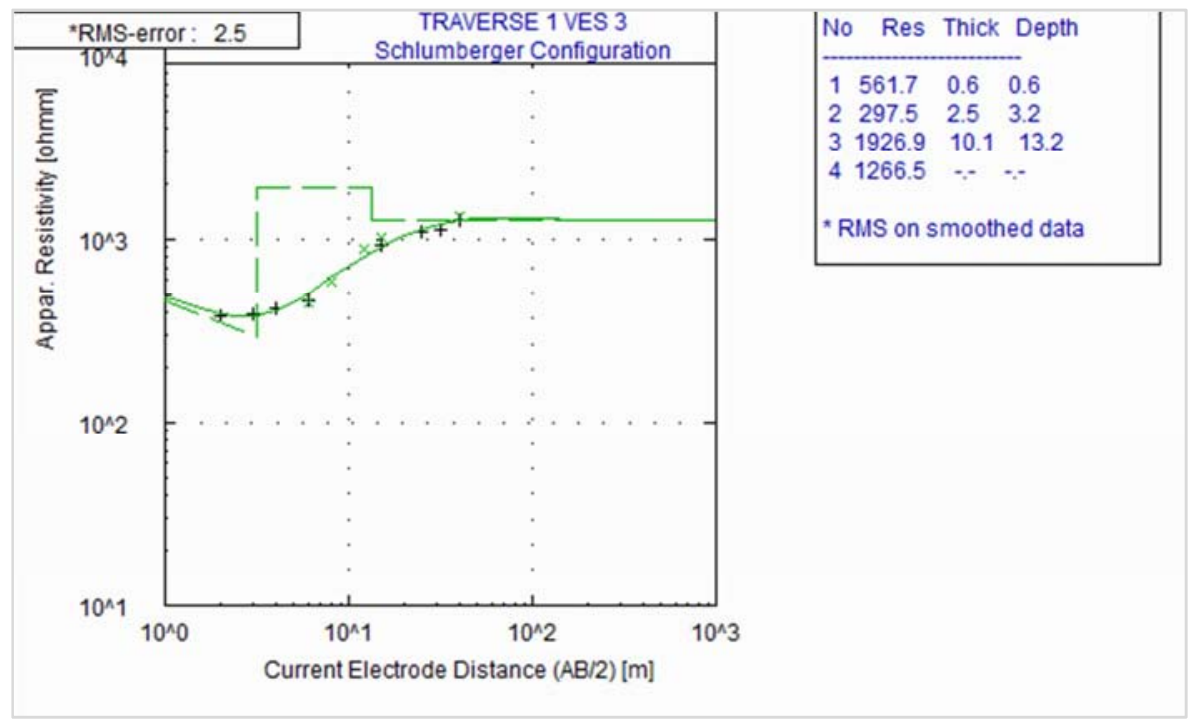

Figure 5. Typical 'HK' sounding curve.

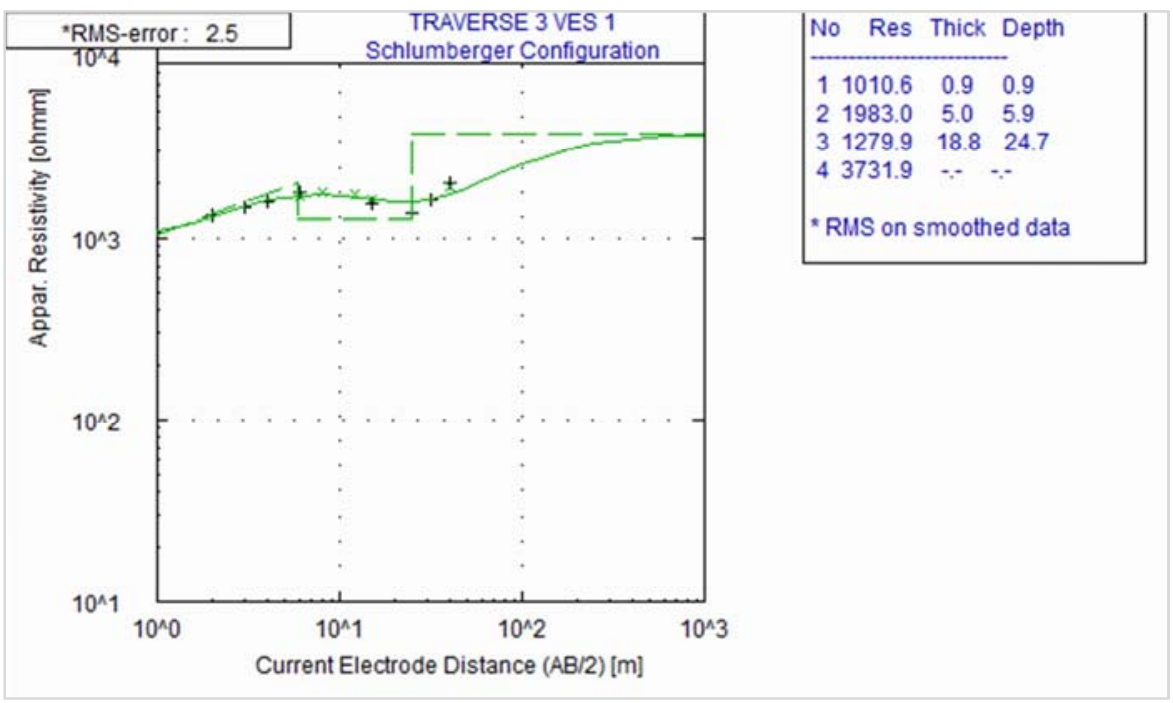

Figure 6. Typical 'KH'sounding curve. 


\subsection{Geoelectric and Lithological Characteristic Along the Three Traverses}

The geo- electric sections were represented by the 2-D view of the geo-electric parameters (depth and resistivity) derived from the inversion of the electrical resistivity sounding data The geoelectric section along Traverse 1 to traverse 3 (Figure 6 to 9) attempted to correlate the geoelectric sequence across the study area. The geoelectric sections identified three geoelectric/geologic subsurface layers. The topsoil comprising of clay, clayey sand, sandy clay and sandstone with the resistivity values ranges from
128 to $1101 \Omega-\mathrm{m}$ with its thickness varies from 0.6 to $1.2 \mathrm{~m}$, the clayey coarse sand comprises of clay and clayey sand with resistivity values range from 225 to $383 \Omega-\mathrm{m}$ and thickness ranges from 3.4 to $13.2 \mathrm{~m}$ while the sandstonelayer resistivity varies from 1267 to $3732 \Omega-\mathrm{m}$. The resistivity values of the topsoil are indicative of clay, sandy clay, and clayey sand. This layer may not be of any particular interest since topsoil is usually excavated. Hence, the foundation of the proposed structures was founded within the upper $2 \mathrm{~m}$ which is clayey in nature.

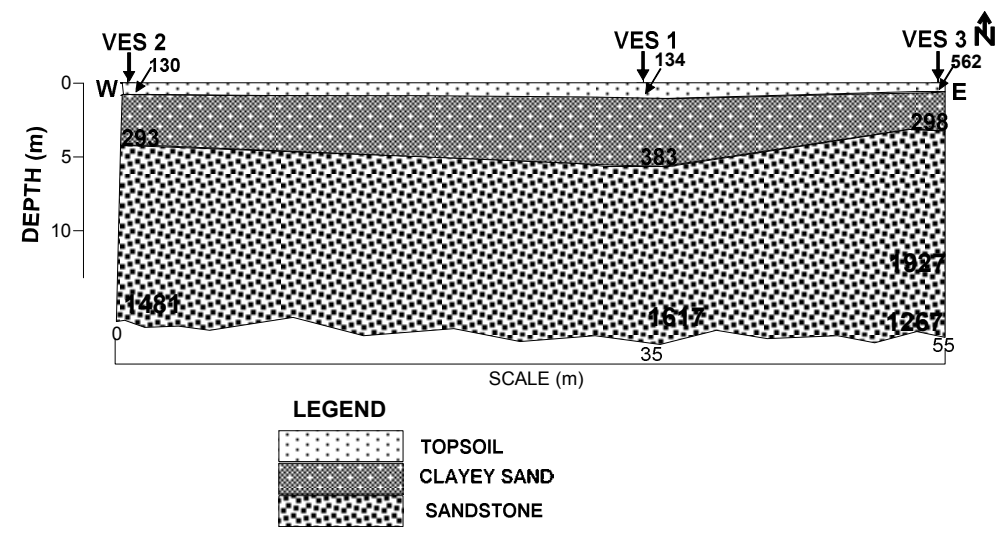

Figure 7. Geoelectric Section along Traverse One.

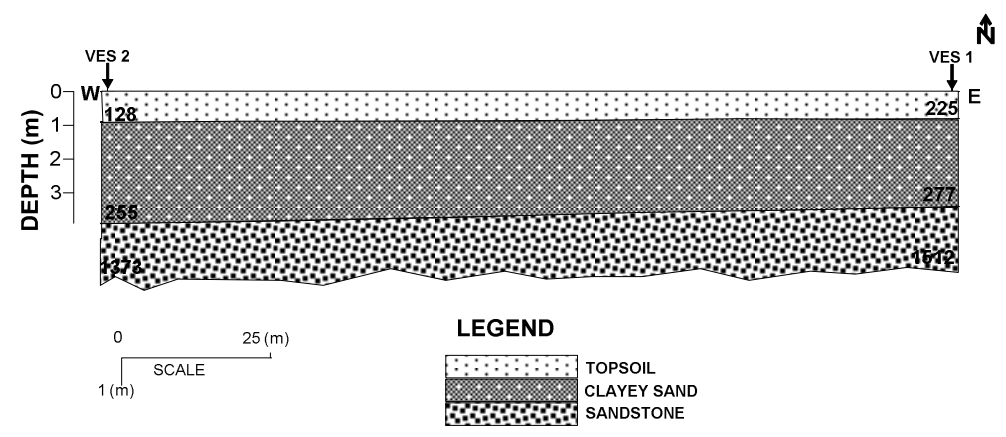

Figure 8. Geoelectric Section along Traverse Two.

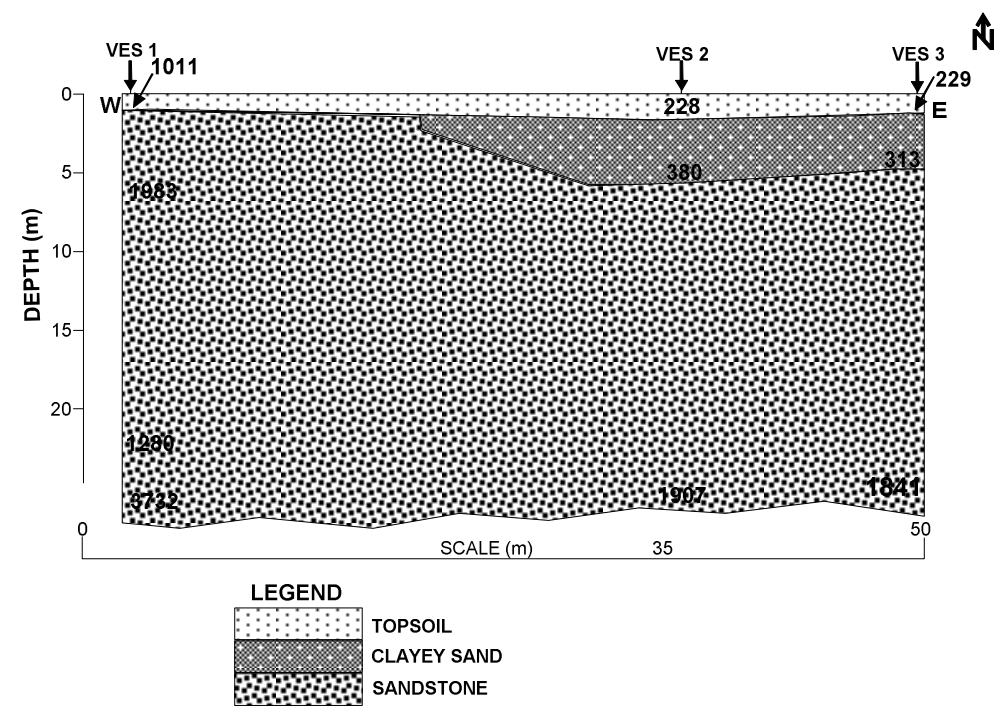

Figure 9. Geoelectric Section along Traverse Three. 


\subsection{Dipole-dipole Pseudosection}

The 2-D Pseudosection was produced from the dipoledipole data taken along the three (3) traverses Figure (10-12). The Dipole-Dipole traverses covered a distance of about 60 meter along East to West Orientation. It delineated three to four major subsurface material/layer components, identified with various colour for easy characterisation; The layer lithological materials varies from Topsoil comprises of clay, clayey sand and sandy clay material as indicated in green/bluecolour with layer resistivity variation of 119 to $207 \Omega \mathrm{m}$. Following this layer is another characterised by low resistivity variation from 207 to $459 \Omega \mathrm{m}$ with the dominant resistivity being between $15.6 \Omega \mathrm{m}$ and $112.6 \Omega \mathrm{m}$. These are as characterised by lithologic units that can be classified sandy shales, and shaly sands, with layer thickness varying from 1 to $25 \mathrm{~m}$ they are indicated with green, light green, and green/blue colour. These zones are characteristically weak and made up of attributes of low foundation integrity. The few zones with materials of high/moderate integrity can be found around the pegging of the traverse within 35 to $45 \mathrm{~m}$ to a depth of $5 \mathrm{~m}$ along traverse one and two, also within 10 to $25 \mathrm{~m}$ along traverse three.

TR1 (Field Data Pseudosection)

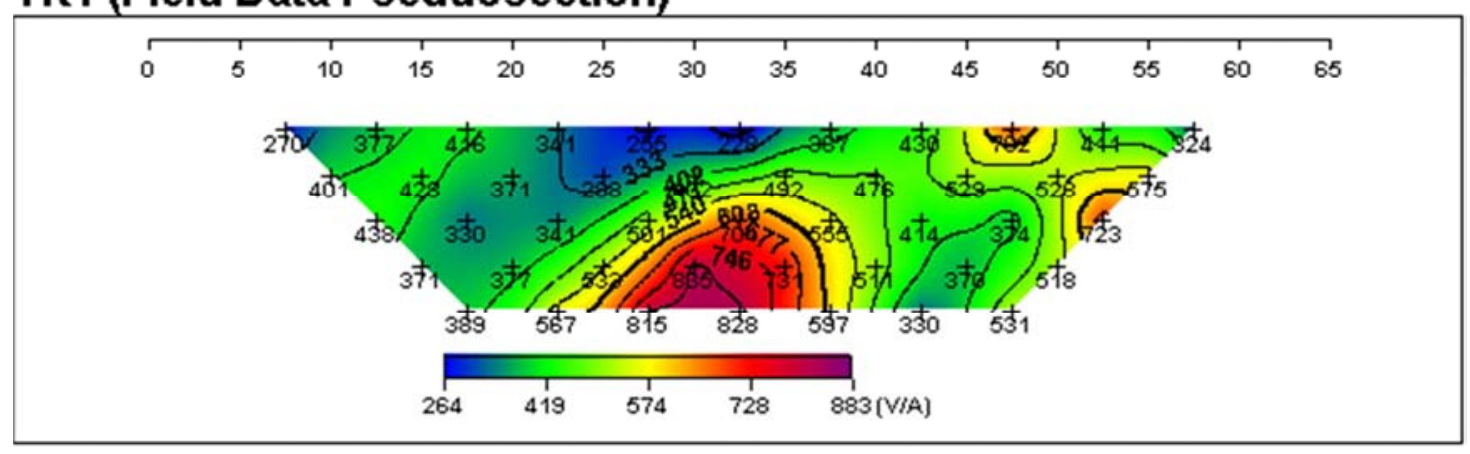

TR1 (Theoretical Data Pseudosection)

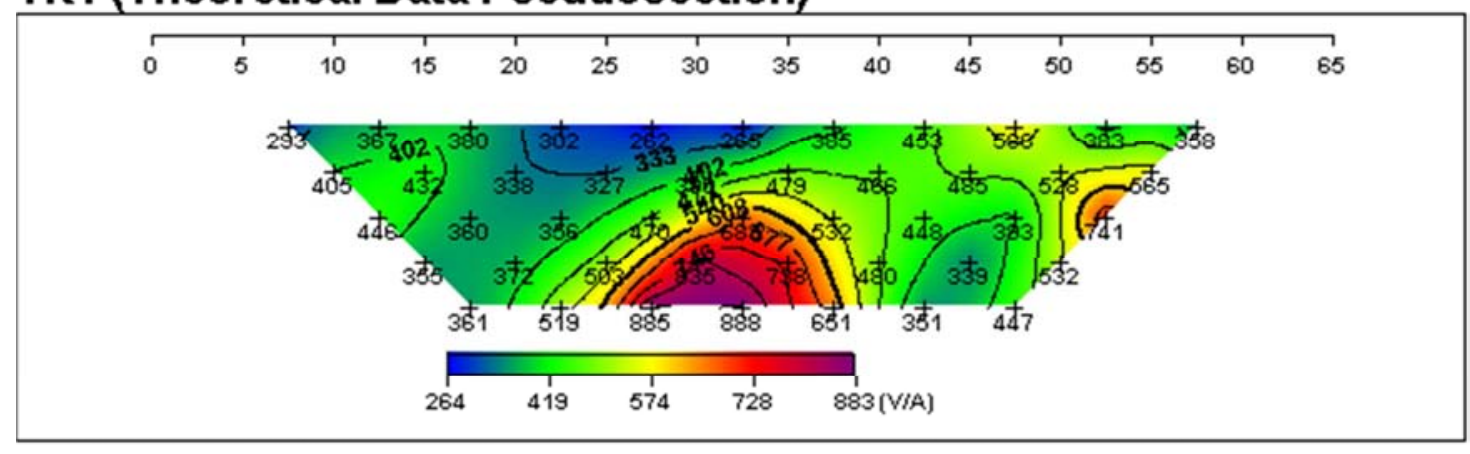

\section{TR1 (2-D Resistivity Structure)}

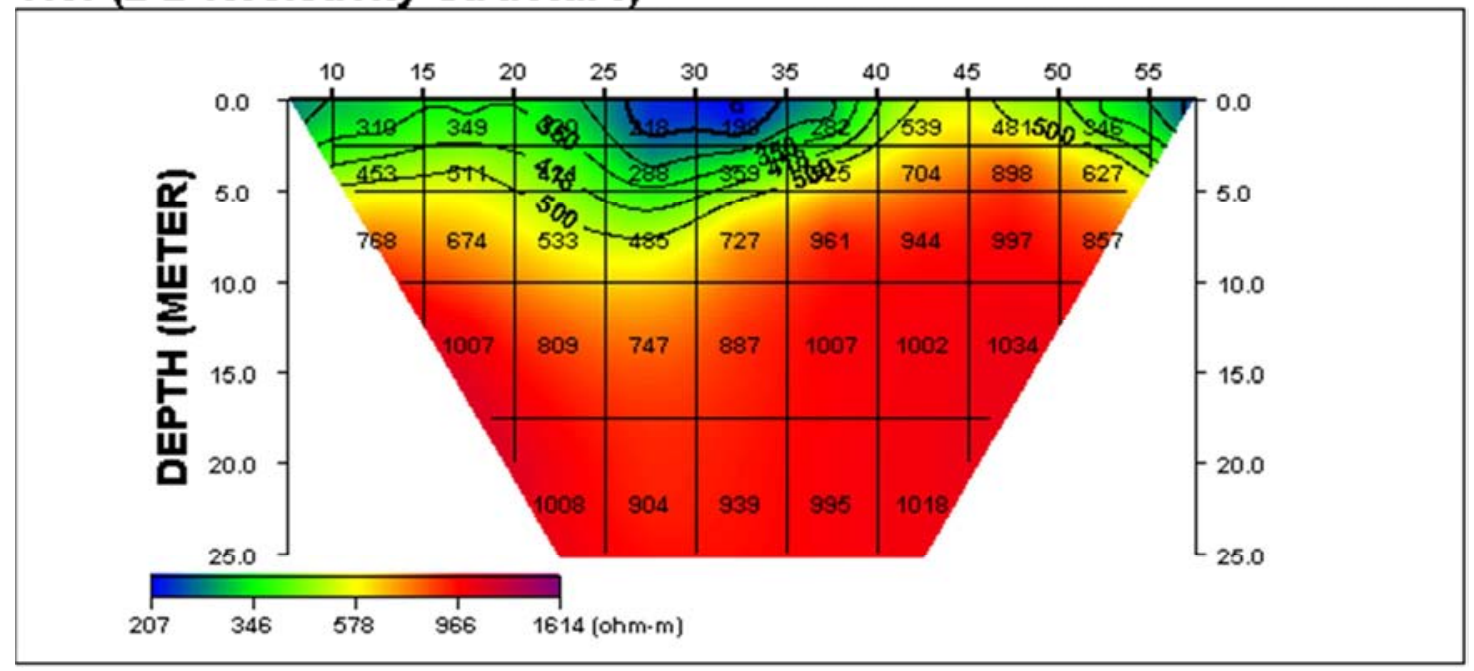

Figure 10. Dipole-Dipole Pseudo-section along Traverse One. 
TR 2 (Field Data Pseudosection)

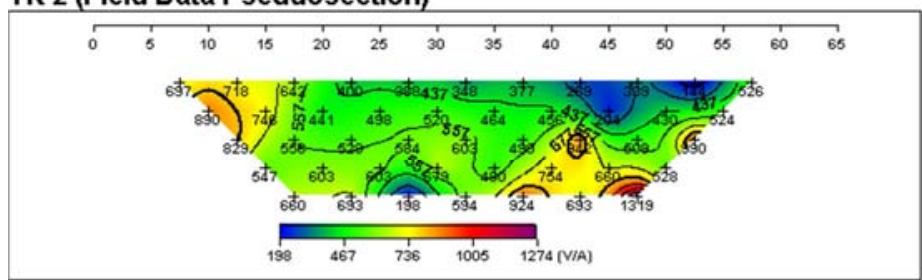

TR 2 (Theoretical Data Pseudosection)

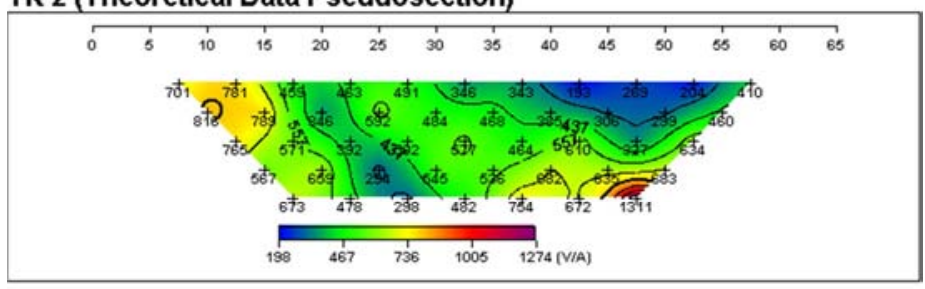

TR 2 (2-D Resistivity Structure)

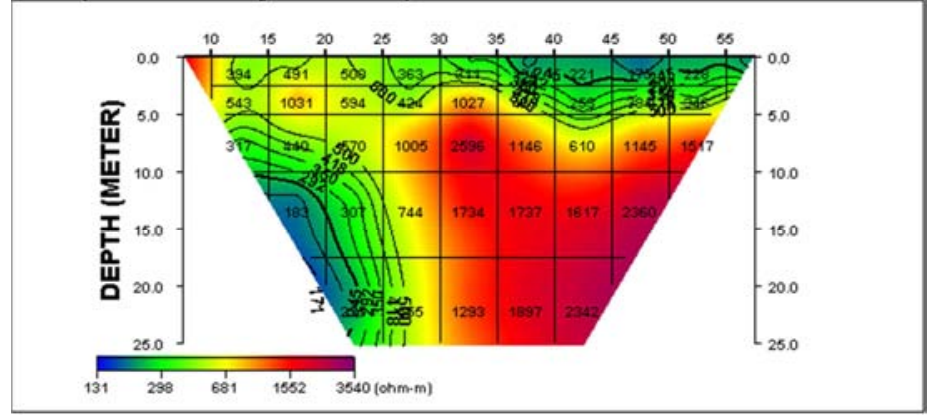

Figure 11. Dipole-Dipole Pseudo-section along Traverse Two.

TR 3 (Field Data Pseudosection)

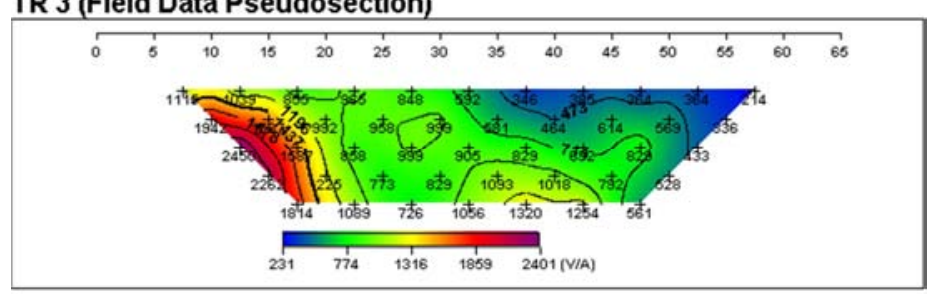

TR 3 (Theoretical Data Pseudosection)

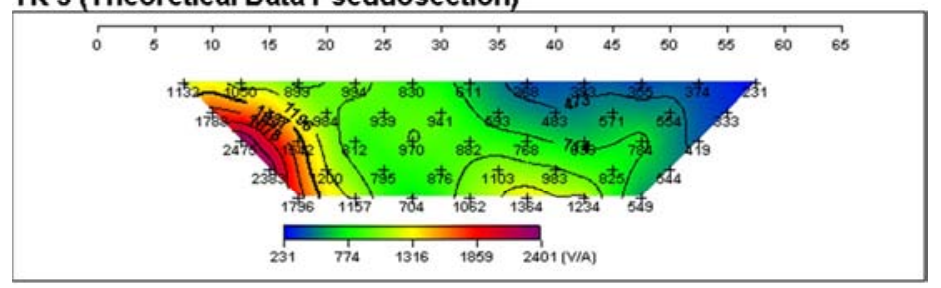

TR 3 (2-D Resistivity Structure)

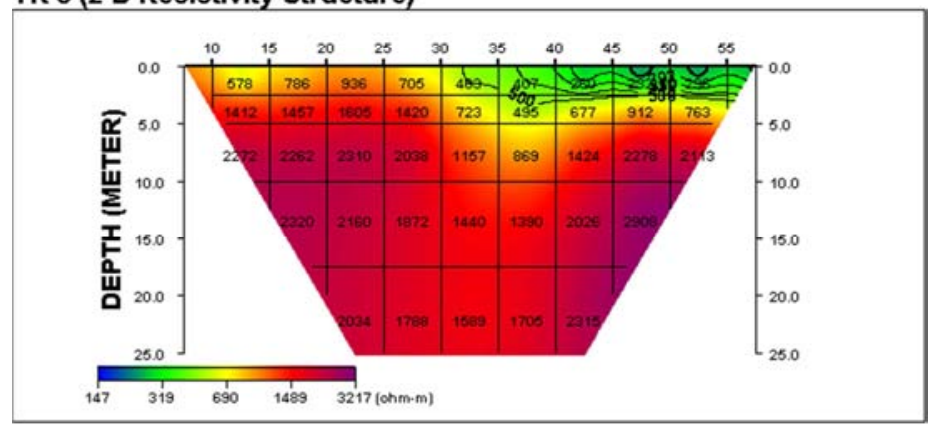

Figure 12. Dipole-Dipole Pseudo-section along Traverse Three. 


\subsection{Horizontal Profilling}

Horizontal profiling was produced from the Wenner data obtained along the traverse one and three (Figure 13 and 14). The results obtained further revealed that the zone is generally weak with apparent resistivity varying from 10 to $200 \Omega$ mbetween 30 to $40 \mathrm{~m}$ along traverse one while within 5 to $25 \mathrm{~m}$ demonstrated fear competence with apparent resistivity value ranging from 380 to $400 \Omega \mathrm{m}$ (Figure 7a). Weak zone was also observed within the 30 to $55 \mathrm{~m}$ along traverse three with apparent resisitivity varying from 200 to $280 \Omega \mathrm{m}$ (Figure 7b).

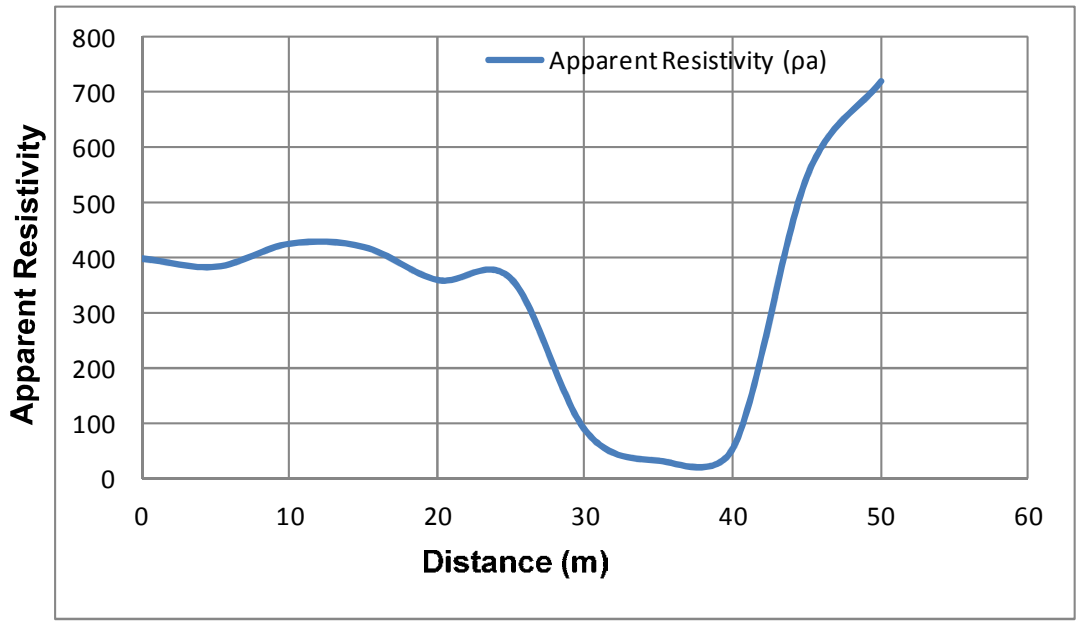

Figure 13. Horizontal Profiling along Traverse One.

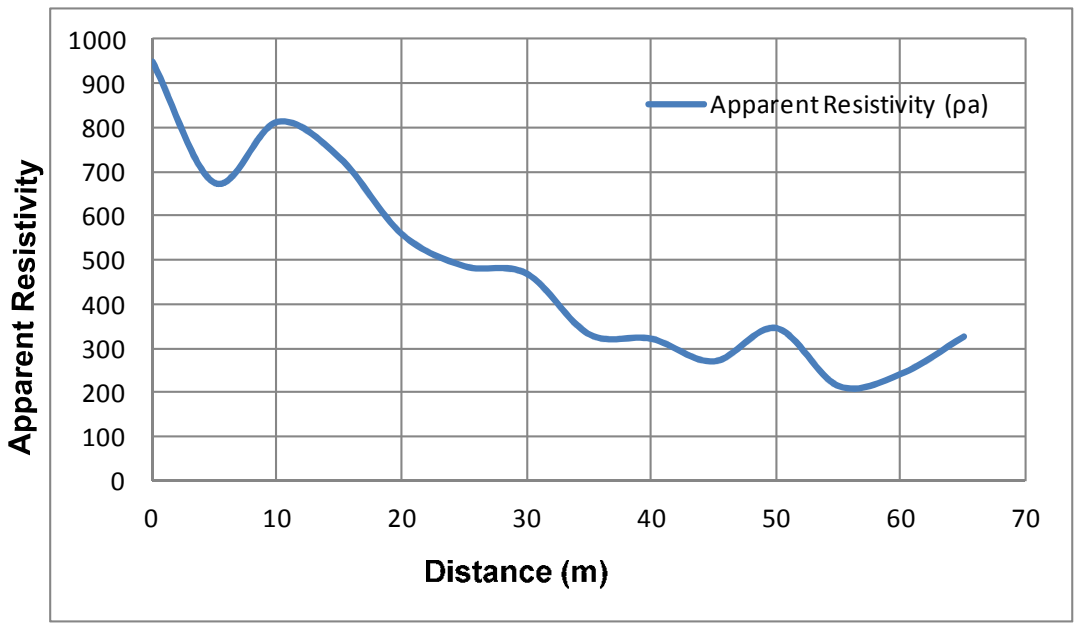

Figure 14. Horizontal Profiling along Traverse Three.

\subsection{Synthesis of Results}

Figure 13 displays the correlation of result obtained from the geophysical techniques along traverse one which clearly showed that they complement each other. The Wenner profiling observed at a distance 25 to $40 \mathrm{~m}$ demonstrated weak zone with apparent resistivity value ranging from 10 to $200 \Omega \mathrm{m}$ which coincides with the low resistivity zone (weak zone) Observed on the dipole-dipole pseudo-section at a distance 25 to $40 \mathrm{~m}$. This also agree with the depression observed on the geo-electric section at the same distance which indicate low integrity and the causes of the differentiate settlement. Also the low resistivity zone (weak zone) Observed on the dipole-dipole pesudosection at distance between 10 to $25 \mathrm{~m} \mathrm{~m}$ at depth of 0 to $25 \mathrm{~m}$ coincide with the depression observed on the geo-electric section at distance 10 to $25 \mathrm{~m}$ on Figure 16. The Wenner profiling zone is generally weak with apparent resistivity varying from 180 to $300 \Omega \mathrm{m}$ at a distance of 30 to $60 \mathrm{~m}$ correlate with the low resistivity zone observed on the dipole-dipole pseudo-section at distance between 30 to $60 \mathrm{~m}$ and with the depression observed on the geo-electric section which indicates low integrity (Figure 17). Correlating the electrical resistivity methods employed along traverses one and three highly show a weak zone with portion of classroom designated on this weak zone. These weak zones contributed a great deal to the cracks observed on the classroom block (figure 9). The presence of clay materials beneath the classroom could also be a contributor to the cracks observed. These results reveal that the Electrical resistivity techniques used for this study are complimentary. 


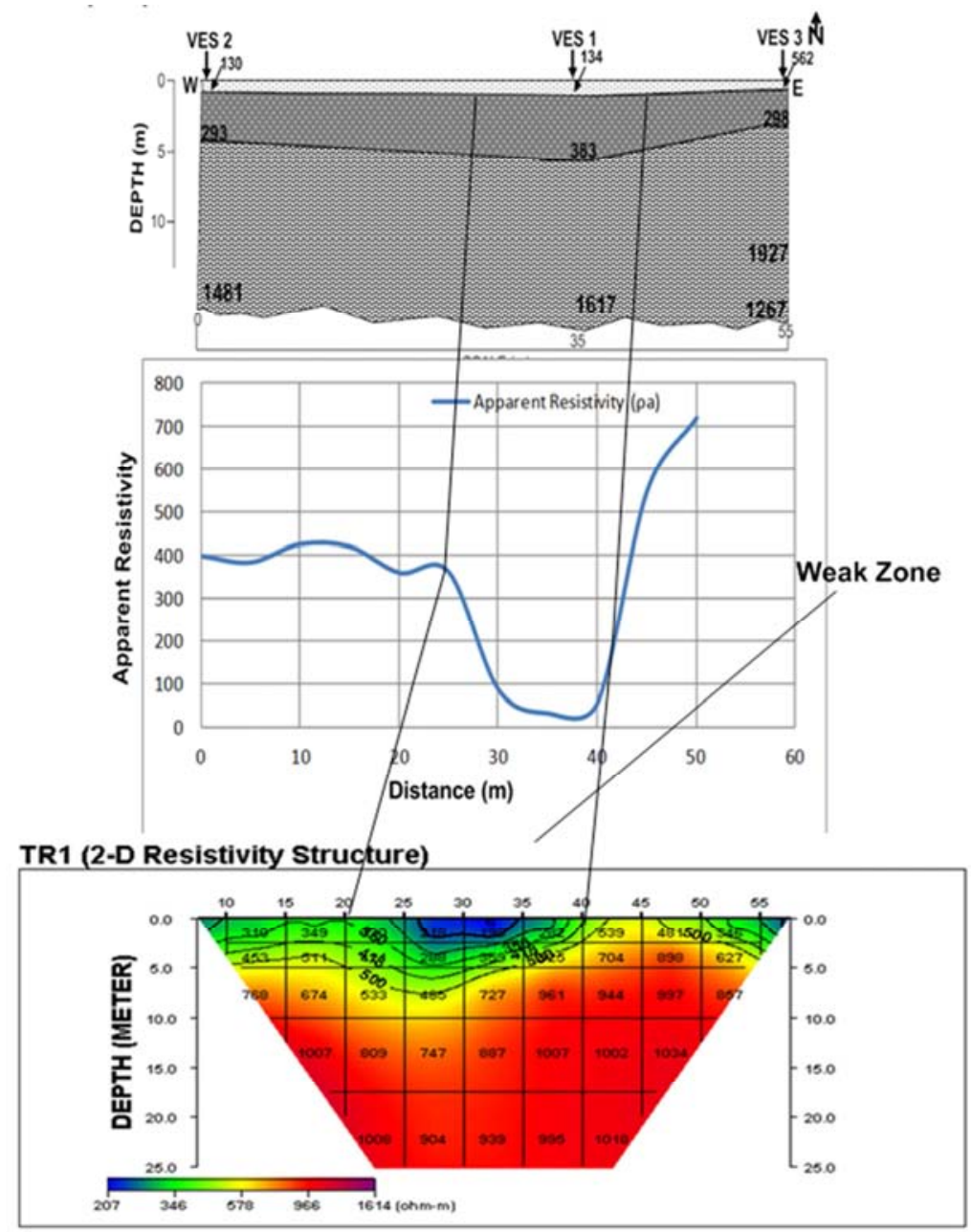

Figure 15. Correlation of Results along Traverse one.

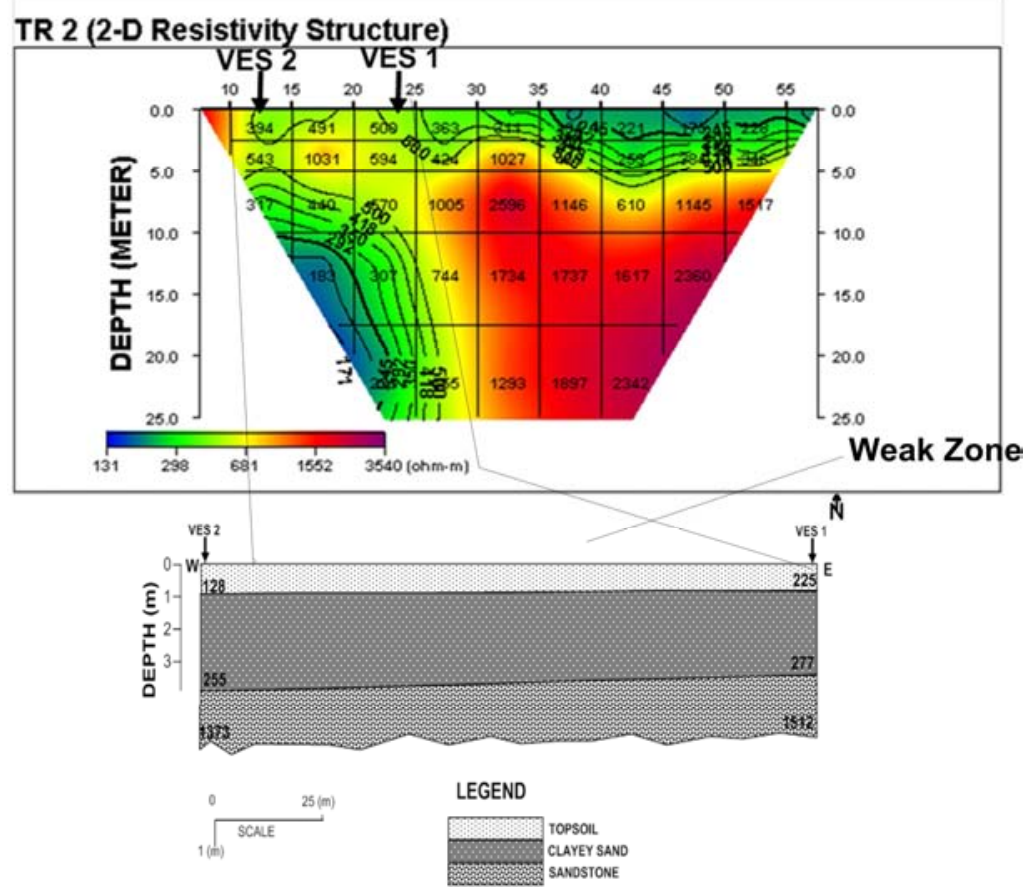

Figure 16. Correlation of Results along traverse two. 


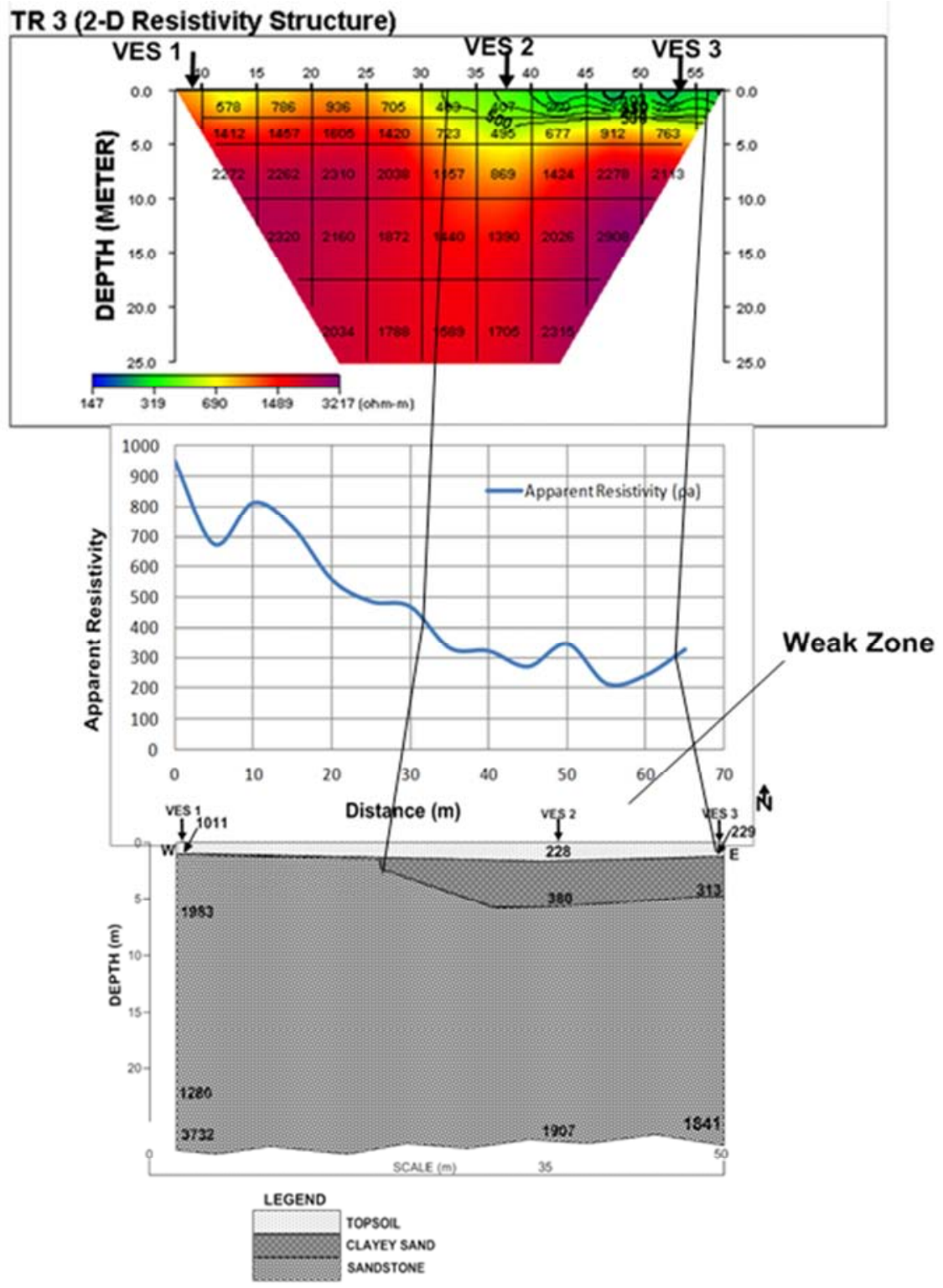

Figure 17. Correlation of Results along traverse Three.

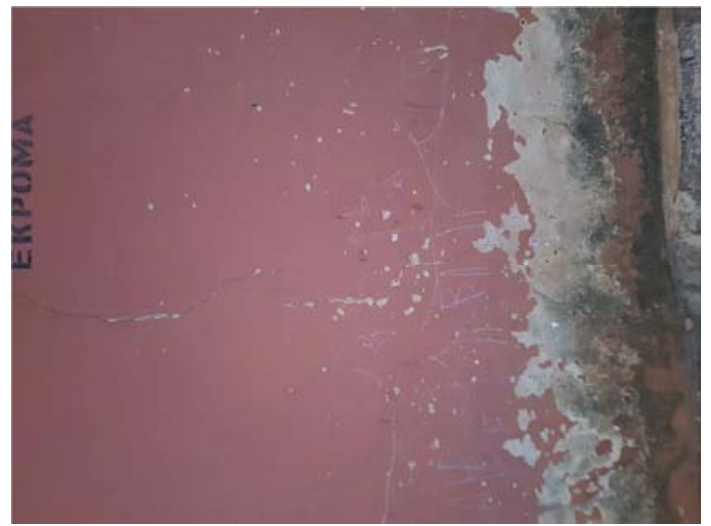

Figure 18. Showing the Cracks in the Building Located Along Traverse 3.

\section{Conclusion}

The study has shown the relevance of geophysical site study for foundation design consideration. The investigation was carried out at Ikekogbe Primary School, Ekpoma, Edo State; where buildings in the study area were severely damaged by a series of cracks as pronounced on the walls of the buildings which affect their stability. The objective is to investigate the cause (s) of building failures in the area whether it is precipitated by geological factors or otherwise. The results obtained from VES delineated three to four geoelectric units which comprises of topsoil, clay sand, sandy clay and sandstone units. From the comprehensive interpretation it is deduced that: the failures of these buildings arise from two factors which are incompetent clay materials and lateral inhomogeneity. All the results correlate well with one another showing that all the techniques used are complemented. No building can be constructed successfully in this area and most other part of the country with similar formation where clay or shale is a major factor without a thorough geophysical studies and information that 
will assist the construction Engineers; at using the right materials as well as excavating to a specific depth with a view to replacing the shale/clayey material with necessary competent materials, complement with reinforcement and proper drainage.

\section{References}

[1] Adelusi A. O., Akinlalu A. A., Daramola B. W. (2014). Integrated geophysical methods for post construction studies: Case study of Omuo Comprehensive High School, Omuo Ekiti, Southwestern, Nigeria, Global J, of Sci. Frontier. 14 (2): 2249-4626.

[2] Adelusi A. O., Akinlalu A. A., Nwachukwu A. I. (2013). Integrated geophysical investigation for post construction studies of buildings around School of Science area, Federal University of Technology, Akure, Southwestern, Nigeria. Int. J. of Physical Sciences. 8 (15): 657669.

[3] Ako, B. D and Olorunfemi, M. O. (1989). Geoelectric Survey for Groundwater in the Newer Basalts of Vom, Plateau State. Journal of Mining and Geology, Vol. 25, Nos 1 \& 2, pp. 247250.

[4] Akintorinwa, O. J. and Adeusi, F. A (2009). Integration of Geophysical and Geotechnical Investigations for a Proposed Lecture Room Complex at the Federal University of Technology, Akure, SW, Nigeria. Journal of Applied Sciences Vol. 2 (3), pp 241-254.

[5] Aigbedion I. (2007). Geophysical investigation of road failures using electromagnetic profile, along UhieleUwenlegbe road, Ekopma, Edo State, Nigeria Middle East Journal of scientific research, 2 (3), 1-4.

[6] Dippro for Windows Dippro TM Version 4.0 Processing and Interpretation software for Dipole Dipole electrical resistivity data. KIGAM, Daejon, South Korea; 2000.
[7] Ilugbo S. O., Adebo A. B., Ajayi O. A, Adewumi O. O and Edunjobi H O. (2018). Geophysical and Geotechnical Studies of a Proposed Structure at Akure, Southwestern Nigeria, Journal of Engineering Research and Reports, 2 (2): 1-12.

[8] Okwueze E. E. (1996). Preliminary Findings of the groundwater resources potential from a Regional Geoeletric Survey of the Obudu Basement area Nigeria, Glob Journal pure Applied Science, 2 (2), 201-210.

[9] Kogbe, C. A. (1978). Geology of Niger Elizabelt publishing company Lagos-Nigeria.

[10] Okeke O. C., Onyekuru S. O., Uduehi G. and Israel H. O. (2011). Geology and hydrogeology of Northern Ishan district, Edo State, Southwestern Nigeria, Vol. 1 (1), 1-11.

[11] Oyedele K. F., Oladele S. and Adedoyin O. (2011). Application of geophysical and geotechnical methods to site characterization for construction purposes at Ikoyi, Lagos, Nigeria. J. Earth Sci. Geotech. Eng. 1 (1): 87-100.

[12] Ozegin, K. O., Bawallah, M. A., Ilugbo S. O., Olaogun, S. O., Oyedele, A. A., and Iluore, K. (2019). Susceptibilty Test for Road Construction: A Case Study of Shake Road, Irrua, Edo State, Global Journal of Science Frontier Research: H Environment \& Earth Science, Vol. 19 (1), 45-53.

[13] Salufu S. O. (2014). The geology of Ekpoma, Journal of Science, Ekp, Vol 1 (10), 11-132.

[14] Salufu S. O and Ujuanbi O. (2015). The Geology And Structural Geology OfEkpoma And Irrua: Implication For TheHydrology And Hydrogeologic Setting Of The Areas, Nigerian Annals Of Natural Sciences, Vol. 15 (1), Pp. 131138.

[15] Sharma V. P. (1997). Environmental and engineering geophysics. Published by Cambridge University Press, United Kingdom. 40-45.

[16] Vander Velpen B. P. A. (2004). Win RESIST Version 1.0 Resistivity Depth Sounding Interpretation Software. M.Sc. Research Project, ITC, Delf Netherland. 